\section{幽闹 Digital Commons@}

Loyola Marymount University

LMU Loyola Law School
Loyola of Los Angeles International and Comparative Law Review

\title{
When Two Giants Collide: Article 17 and the Scope of Trademark Protection Afforded under the TRIPS Agreement
}

Katja Weckstrom

Follow this and additional works at: https://digitalcommons.Imu.edu/ilr

Part of the Law Commons

\section{Recommended Citation}

Katja Weckstrom, When Two Giants Collide: Article 17 and the Scope of Trademark Protection Afforded under the TRIPS Agreement, 29 Loy. L.A. Int'I \& Comp. L. Rev. 167 (2007).

Available at: https://digitalcommons.Imu.edu/ilr/vol29/iss2/1

This Article is brought to you for free and open access by the Law Reviews at Digital Commons @ Loyola Marymount University and Loyola Law School. It has been accepted for inclusion in Loyola of Los Angeles International and Comparative Law Review by an authorized administrator of Digital Commons@Loyola Marymount University and Loyola Law School. For more information, please contact digitalcommons@lmu.edu. 


\title{
When Two Giants Collide: Article 17 and the Scope of Trademark Protection Afforded Under the TRIPS Agreement
}

\author{
KATJA WECKSTRÖM*
}

\section{INTRODUCTION}

International intellectual property law overtly merged with international trade law in 1995 in the Agreement on TradeRelated Aspects of Intellectual Property Rights ("the TRIPS Agreement").' Although both fields of law have a long international history, each operates on fundamentally different premises. While international trade law focuses on removing trade barriers, intellectual property rights are territorially limited and hence, by definition, barriers to trade. The 'merger' was accompanied by an unforeseen depth of commitment by sovereign nations to the World Trade Organization ("WTO") and its rules.

While bringing a new subject matter within the trade regime broadened the scope of international economic regulation, the enforcement mechanism established within the framework of the WTO also seemingly rendered international trade law more pervasive than ever in relation to its subjects. ${ }^{2}$ Thus, at least from a formal point of view, the international trade regime of today is a system governed by the rule of law, not that of diplomacy. ${ }^{3}$

\footnotetext{
- IP Fellow and Visiting Adjunct Faculty at Chicago-Kent College of Law. LL.D. Candidate at University of Turku, Finland. The author would like to thank Graeme Dinwoodie, Sungjoon Cho, and Sarah Harding for valuable comments and discussions during the writing process.

1. See Agreement on Trade-Related Aspects of Intellectual Property Rights, Apr. 15, 1994, 108 Stat. 4809, 1869 U.N.T.S. 299 [hereinafter TRIPS Agreement].

2. See Gary P. Sampson, Overview, in THE ROLE OF THE WORLD TRADE ORGANIZATION IN GLOBAL GOVERNANCE 3-4 (Gary P. Sampson ed., 2001).

3. See JOOST PAUWELYN, CONFLICT OF NORMS IN PUBLIC INTERNATIONAL LAW: How WTO LAW RELATES TO OTHER' RULES OF INTERNATIONAL LAW 25 (2003); Martin Wolf, What the World Needs From the Multilateral Trading System, in THE ROLE
} 
These changes naturally trigger a number of questions. What is the scope of the TRIPS Agreement and how should its provisions be interpreted under existing rules of international law? Do national legislators continue to serve a function within the international trade regime, other than being mere implementing organs? In trademark terms, is the minimum standard of trademark protection set forth in the TRIPS Agreement really a maximum standard of other Intellectual Property ("IP") protection? To what extent does the international level of trademark protection in the TRIPS Agreement restrict the ability of the national legislator, under international law, to regulate within the area of trademark law and other areas of law?

Article 16 of the TRIPS Agreement sets forth the minimum standard of trademark protection that Member States are obligated to afford. ${ }^{4}$ However, Article 17 of the TRIPS Agreement provides that Member States are allowed to provide for limited exceptions to the afforded rights. ${ }^{5}$ In European CommunitiesProtection of Trademarks and Geographical Indications for Agricultural Products and Foodstuffs ("the GI-report"), the WTO Panel had to resolve the relationship of Articles 16 and 17 to other provisions of the TRIPS agreement, namely, Article 24, which affords protection for Geographical Indications ("GIs"). ${ }^{6}$

One of the most contested issues in the international trade and intellectual property arenas arises when the protection of trademarks conflicts with the protection of GIs. The GI-report gives some insight into what international trademark law mandates. That same report also gives some guidance on how conflicts between different IPRs should be resolved. This Article provides a deeper analysis of the coexistence of rights in the framework of the TRIPS Agreement-a relationship that will inevitably grow in importance when trade-related issues permeate all WTO IP issues.

OF THE WORLD TRADE ORGANIZATION IN GLOBAL GOVERNANCE, supra note 2, at 185; see also JOHN H. JACKSON, THE JURISPRUDENCE OF GATT AND THE WTO: INSIGHTS ON TREATY LAW AND ECONOMIC RELATIONS 181 (2000).

4. TRIPS Agreement, supra note 1, art. 16; see Appellate Body Report, United States - Section 211 Omnibus Appropriations Act of 1998, Tl 186, WT/DS176/AB/R (Jan. 2, 2002).

5. TRIPS Agreement, supra note 1, art. 17.

6. See Panel Report, European Communities-Protection of Trademarks and Geographical Indications for Agricultural Products and Foodstuffs, 9 \1 7.632, 7.637-.686, WT/DS290/R (Mar. 15, 2005) [hereinafter EC Panel Report]. 
As existing international trademark law has yet to fulfill the market regulatory function it serves on the national level, this Article adopts a new approach to analyzing international trademark law. First, a study of three cases around the world reveals how and when trademarks can be viewed as property through use of different property concepts. Then, the Western concept of trademarks as property (derived from possession) is contrasted to the Maori concept of property (derived from the use of property).

The property discussion is not new to trademark law in the United States or elsewhere, nor is a discussion on the significance of trademark use in trademark law.' Here, however, the discussions are combined and analyzed in an attempt to provide a framework for deciding international trademark cases. This Article is not primarily concerned with a defendant's use of a sign as a trademark, nor the proprietor's right to property. Instead, it argues that the property rights in a trademark should be assessed through its use; any finding of infringement hinges upon whether the proprietor's use of the trademark is unlawfully affected by a third party's use of an identical or similar sign. The focus is neither on the proprietor nor on the mark itself, but on the protected use.

Second, the analytical framework is supported by an analysis of the international legal system. Then, the analytical framework, informed by property theory and international law, is applied to the issues raised in the GI-report. This leads to the conclusion that the GI-report is flawed in certain respects.

This Article argues that the text of the TRIPS Agreement, when infused with the general principles of public international law, although seemingly vague, provides a binding analytical framework for assessing the legitimate scope of trademark protection under international law. The existing analytical framework can be derived from three sources: (1) the minimum standard of protection set forth in the agreement under Article 16, (2) the degree of derogation allowed from the afforded rights

7. See Ilanah Simon, Embellishment: Trade Mark Use Triumph or Decorative Disaster, 28(6) Eur. INTELl. Prop. Rev. 321 (2006); Graeme B. Dinwoodie \& Mark D. Janis, Confusion over Use: Contextualism in Trademark Law 17 (Univ. of Iowa College of Law, Working Paper No. 06-06, 2006), available at http://ssrn.com/abstract=927996. See generally Stacey L. Dogan \& Mark A. Lemley, Trademarks and Consumer Search Costs on the Internet, 41 HOUS. L. REV. 777 (2004). 
under Article 17, and (3) the context and structure of the TRIPS Agreement. ${ }^{8}$

The analytical framework rests on a contextual approach to interpreting the TRIPS Agreement. ${ }^{9}$ Just as the meaning of each word in each provision rests not only on the ordinary meaning of the word, but also on the context in which it is used, the meaning of each provision should be interpreted in context with the other provisions of the treaty. This Article argues that an overly literal interpretation, with the effect of drawing arbitrary lines between different intellectual property rights ("IPRs"), is inconsistent with the TRIPS Agreement. ${ }^{10}$

Section II explores the nature of the rights Article 16(1) of the TRIPS Agreement guarantees trademark owners by scrutinizing trademark rights as a legal concept. The Article approaches this question by way of analogy to property law; it inquires to what extent trademark rights can be viewed as

8. After determining that a right may be limited by a country's regulation, the Panel: [E]xamines whether Article 16.1 of the TRIPS Agreement requires Members to make available to trademark owners the right [and if] it does, [it] will consider whether Article 24.5 provides authority to limit that right and, if Article 24.5 does not, conclude . . . by assessing whether Article 17 or Article 24.3 of the TRIPS Agreement permits or requires the European Communities to limit that right ....

EC Panel Report, supra note 6, If 7.519. "A treaty interpreter must begin with, and focus upon, the text of the particular [treaty] provision to be interpreted." Appellate Body Report, United States - Import Prohibition of Certain Shrimp and Shrimp Products, II 114, WT/DS58/AB/R (Oct. 12, 1998) [hereinafter U.S. Shrimp Appellate Body Report]. If the ordinary meaning is equivocal or inconclusive, then "the object and purpose of the treaty as a whole may usefully be sought." Id. Hence, a panel should address the questions in this order, i.e. from the specific to the general.

9. See BlaCK'S LAW DiCTIONARY 338 (8th ed. 2004) (defining context as "the surrounding text of a word or passage, used to determine the meaning of that word or passage"); OXFORD ENGLISH DICTIONARY 820-21 (2d ed. 1989) (defining context as the "connected structure of a writing or composition" or the "whole structure of a connected passage regarded in its bearing upon any of the parts which constitute it; the parts which immediately precede or follow any particular passage or 'text' and determine its meaning"). But see PAUl CRAIG \& GRÁINNE DE BÚRCA, EU LAW: TEXTS, CASES, AND MATERIALS 98 (3d ed. 2003) (describing the interpretive approach in which the interpretation that furthers the objective and purpose of the treaty prevails over the one that runs contrary to it).

10. See generally EC Panel Report, supra note 6, II 7.631-.632 (stating that because Article 24(3) appears in section three of Part II of the TRIPS Agreement, the reference to "this Section" is therefore a reference to section three, which sets out standards for the protection of GIs, and that the scope of Article 24(3) was limited by the introductory phrase "[i]n implementing this Section"). 
property ${ }^{11}$ and explores how different understandings of property influence interpretation of international trademark law. This analysis serves as a foundation for determining how viewing trademark rights as property affects the rights when interacting with other interests in society, i.e. when the rights clash with other equally fundamental interests.

Section III focuses on the relationship between the explicit limitations set forth in Article 16(1) and the limitations that are allowed by virtue of Article 17 in light of the GI-report. ${ }^{12}$ The GIPanel was faced with a complaint that a European Community regulation protecting GIs allegedly encroached upon the minimum level of trademark protection mandated by the TRIPS Agreement.

Section IV approaches the TRIPS Agreement through the interpretive lens of general rules of international law and international trade law. ${ }^{13}$ According to customary international law, treaty provisions should be interpreted narrowly. On the other hand, they should not be interpreted so as to render the provisions ineffectual, since each treaty provision was intended to have an effect. ${ }^{14}$ Thus, an interpretation giving some provisions more effect than others is inconsistent with the general objective and purpose of the treaty. Much like WTO panels should not act as an international legislature through activist interpretation, WTO panels should not employ "passivist" interpretation by stalling progress or by shying away from areas of political contention. WTO panels, instead, should interpret the TRIPS Agreement and its provisions in the legal framework and practical context in which they operate. Absent express wording on the specific issue to the contrary, a hierarchy of intellectual property rights should not be presumed to have been included in the TRIPS Agreement. The TRIPS Agreement itself-its mere adoption as well as its structure-supports a presumption of equality.

11. Cf. Michael A. Carrier, Cabining Intellectual Property Through a Property Paradigm, 54 DukE L.J. 1, 4-5 (2004) (stating that "the propertization of IP . . a appears to be irreversible [but] not as absolute as it is often claimed to be.").

12. See generally EC Panel Report, supra note 6, TII 7.644-.686 (discussing how the EC regulations protecting GIs are justified under Article 17 of the TRIPS Agreement).

13. See PAUWELYN, supra note 3 , at 25 .

14. ANTONio CASSESE, InTERnational Law 179 (2d ed. Oxford Univ. Press) (2005) ("[A] treaty must be given an interpretation that enables its provisions to be 'effective and useful,' that is, to have the appropriate effect."); IAN BROWNLIE, Principles of International Public Law 602-07 (6th ed. Oxford Univ. Press) (2003). 
In Section $\mathrm{V}$, the analytical framework produced by this analysis is developed to define the scope and limits of what constitutes the minimum standard of trademark protection under international law. This Article argues that the GI-Panel's reading of the TRIPS Agreement is counter-intuitive; it creates a hierarchy of IPRs that would require Member States to restructure their protective schemes. It is further argued that the TRIPS Agreement-implicitly and explicitly-stands for a presumption of co-existence of rights and the Agreement's provisions should be interpreted accordingly. The TRIPS Agreement does not exist in a vacuum and its interpretation should reflect this.

\section{The Minimum Standard of ARTICle 16(1): Trademark RIGHTS As A LEGAL CONSTRUCT}

\section{A. Trademark Rights As Property}

This Article assumes that trademark rights are property rights. However, this assumption is limited in terms of the information it reveals. The property label only has meaning in the context of property law, which regulates the rights of that which is designated as "property." 15 This section seeks to ascertain how a property right can be defined at the time of its allocation, as well as later when conflicts with other rights emerge. In trademark terms, we seek guidance in defining the object of the right, i.e. an answer to the following question: what do you own when you own a trademark? Three cases, one decided by the Constitutional Court of South Africa and two by the European Court of Human Rights serve as illustrative tools. Each case involves a nontraditional taking of property without compensation. Hence, the cases raised issues concerning whether the object constituted constitutionally protected property and whether it, nonetheless, could legitimately be subject to a taking without compensation. In other words, when evaluating a proprietary interest one must always ascertain whether the object and holder satisfy the requirements for receiving protection and, if so, whether societal considerations of necessity still outweigh the individual interest in receiving protection in the circumstances of each individual case.

15. See generally JEREMY WALdRON, THE RIGHT TO PRIVATE PROPERTY 29-31 (1988) (discussing the problems associated with defining property law). 
In First National Bank of SA Limited t/a Wesbank $v$. Commissioner, ${ }^{16}$ three leased cars had been seized by the Revenue Service for the lessee's unpaid customs debts. First National Bank, the owner of the cars, challenged the government's authority under the constitution to sell the seized vehicles, since they were the property of a third party." Section 25 of the South African Constitution contains a negative guarantee of property rights in the form of protection against arbitrary deprivations. ${ }^{18}$ Although a large portion of Section 25 concerns issues regarding real property, it expressly states that property is not limited to land. ${ }^{19}$ After extensive theoretical and comparative analysis of Section 25, the court held that the provision authorizing the sale was unconstitutional.

The court concluded, on the one hand, that the protection of property in the negative does not include an express guarantee of the right to acquire, hold, and dispose of property. On the other hand, the court acknowledged a guarantee of the right to be free from arbitrary deprivation of property. ${ }^{20}$ The same right extends to both natural and juristic persons $;{ }^{21}$ it is, however, not absolute, but subject to limitation based on societal considerations. ${ }^{22}$

The approach to the interpretation of Section 25 has to be contextual in order to reflect this nature of the right. In the words of the court, "[t]he subsections ... must not be construed in isolation, but in the context of the other provisions of section 25 and their historical context, and indeed in the context of the Constitution as a whole. ${ }^{.23}$ The court cites Professor A.J. van der Walt when it states that it is necessary "to move away from a static, typically private-law conceptualist view of the constitution as a guarantee of the status quo to a dynamic, typically public-law view of the constitution as an instrument for social change and transformation under auspices [and control] of entrenched

16. First Nat'l Bank of S.A. Ltd. v. Comm'r for the South African Revenue Servs. 2002 (4) SA 768 (CC) paras. 2-5, 7-10 (S. Afr.).

17. Id.

18. S. AFr. CONST. 1996, art. 25(1).

19. S. AFR. CONST. 1996, art. 25(4)(b).

20. See generally First Nat'l Bank, 2002 (4) SA 768 (CC) paras. 25, 71 (considering approaches followed by other democratic systems when deciding what constitutes "arbitrary" deprivation).

21. Id. paras. 41,45 .

22. Id. para. 49.

23. Id. 
constitutional values," when considering the purpose and content of the property clause. ${ }^{24}$ Hence, property should also serve the public good. ${ }^{25}$

As an initial matter the court notes that any interference with the use, enjoyment or exploitation of private property involves some degree of deprivation of the title holder's rights. A deprivation per se cannot trigger a duty to compensate. The invalidity of a deprivation hinges upon whether it can be viewed as arbitrary. ${ }^{26}$ Arbitrariness should be evaluated in the legislative context to which the prohibition against "arbitrary" deprivation has to be applied as well as to the nature and extent of the deprivation. ${ }^{27}$ More specifically, it is to be determined by evaluating the relationship between the means employed and the ends sought, as well as the relationship between the purpose for the deprivation and (1) the person whose property is affected, (2) the nature of the property, and (3) the extent of the deprivation. A more compelling purpose needs to be established when the deprivation affects land as opposed to other property as well as when the deprivation embraces all the incidents of ownership as opposed to affecting only some rights in the bundle of rights. ${ }^{28}$

Similarly, in J.A. Pye (Oxford) Ltd. v. the United Kingdom, the European Court of Human Rights agreed with the petitioner that the English law on adverse possession, as applied, violated their fundamental right to protection of property. ${ }^{29}$ Under the law of adverse possession the possessor can acquire lawful title (by way of initiating a registration procedure), if the owner has not asserted rights of ownership against the possessor of land in twelve years. ${ }^{30}$ Petitioner, a company, was the registered owner of twentythree hectares of agricultural land. After the termination of a grazing agreement between petitioner and the Grahams in 1984, the Grahams continued to graze the land without permission until 1999. The action before the court arose when the Grahams applied

24. Id. para. 52 (emphasis and bracketed text in original) (quoting A.J. VAN DER Walt, The CONSTITUTIONAL PROPERTY Clause 11 (1997)).

25. Id. (emphasis and bracketed text in original) (quoting VAN DER WALT, supra note 24.)).

26. Id. paras. 57-61.

27. Id. para. 66 .

28. Id. para. 100.

29. J.A. Pye (Oxford) Ltd. v. United Kingdom, App. No. 44302/02, 43 Eur. H.R. Rep. 3,43 (2006).

30. Id. 
to the registration authority for transfer of title pursuant to the law of adverse possession and petitioner subsequently lost lawful title to the land. ${ }^{31}$

Article 1 of Protocol 1 of the European Convention of Human Rights and Fundamental Freedoms ${ }^{32}$ secures the right of "peaceful enjoyment of one's possessions," except when deprivation is in the public interest, as provided for by law and by the general principles of international law. ${ }^{33}$ According to previous case-law by the European Court of Human Rights, a deprivation must comply with the principle of lawfulness and pursue a legitimate means reasonably proportionate to the aim sought in order to satisfy the general principle of peaceful enjoyment. ${ }^{34}$ Nonetheless, the court recognized that the national legislatures should be shown great deference in determining how to further the public interest and such determination could only be overturned if it is "manifestly without foundation."

The existence of alternatives is not enough to render the contested legislation unjustified. The proper inquiry is whether the interference strikes "a fair balance between the demand of the public or general interest of the community and the requirements of the protection of the individual's fundamental rights." 36 Although a deprivation of property without compensation can be legitimate, the compensation terms set forth in the relevant legislation are important to assess the deprivation's fairness and ultimate legitimacy. ${ }^{37}$

The court stressed that unlike other property that is inherently subject to restriction, qualification or limitation, the petitioner's title to land was absolute. The mere fact that a law of general applicability was in effect at the time of acquisition did not inherently limit petitioner's property right. Whether a law of general applicability can ever do so depends on whether the law can be seen as qualifying or limiting the right, i.e. take effect, at the

31. Id.

32. Protocol to the European Convention for the Protection of Human Rights and Fundamental Freedoms art. I, Mar. 20, 1952, 213 U.N.T.S. 262 [hereinafter ECHR Protocol], available at $\mathrm{http}: / /$ conventions.coe.int/Treaty/en/Treaties/Html/009.htm.

33. Id. art. 15.

34. See Bruncrona v. Finland, App. No. 41673/98, 41 Eur. H.R. Rep. 28, 604 (2005); see also J.A. Pye, 43 Eur. H.R. Rep. 3, at 55-56.

35. J.A. Pye, 43 Eur. H.R. Rep. 3, at 56.

36. Id.

37. Id. 
moment of acquisition rather than pending certain circumstances at some time in the future. ${ }^{38}$ Due to the fact that petitioner had registered title to the land and the public interest therefore was weaker than in the case of unregistered property, the transfer of title to the possessors without compensation was greatly disproportionate to the total revocation of petitioner's property interest. ${ }^{39}$ In the end, the decision seemed to turn on the fact that the law did not require that the owner be given notice during the twelve-year time period. ${ }^{40}$

Of the seven justices on the court, three dissented. ${ }^{41}$ The dissenters stressed that ownership carries not only rights, but duties as well. The duties imposed on petitioner in this case could not be viewed as excessive or unreasonable, since petitioners were professional real estate developers and therefore should have had full knowledge of the law as well as the minimal steps required to look after their interests. Since the convention only imposed a minimum standard of protection and it is open to national legislatures to heighten the level of protection, the majority's decision was unduly influenced by the legislature's decision to modernize the law of adverse possession. ${ }^{42}$

In Anheuser-Busch Inc. v. Portugal, the European Court of Human Rights concluded that a trademark application can give rise to a protectable property interest based on legitimate expectations. ${ }^{43}$ Anheuser-Busch argued that the enjoyment of a property right afforded at the time of application could not be disturbed absent specific law to this point. ${ }^{44} \mathrm{~A}$ Czech holder of a GI had successfully opposed the trademark application in extensive opposition proceedings. ${ }^{45}$ Consequently, the trademark registration never issued.

38. Id. at $57-58$.

39. Id. at $62-63$.

40. Id. at 63 . The court placed great weight on the fact that the act had been amended in 2002 to include a requirement of notice after ten years of possession. See id. Throughout the opinion the court emphasized that the applicant was deprived of (1) property (2) without compensation (3) without the ability to contest the decision in court. See id.

41. Id. at 65 (Maruste, Garlicki \& Borrego Borrego, JJ., dissenting).

42. Id. (Maruste, Garlicki \& Borrego Borrego, JJ., dissenting).

43. Anheuser-Busch, Inc. v. Portugal, App. No. 73049/01, para. 47 (2005), http://cmiskp.echr.coe.int/tkp197/search.asp?skin=hudoc-en (search for application number "73049/01", then follow the link for the Oct. 11, 2005 decision) (last visited Apr. $22,2007)$.

44. Id. para. 32 .

45. Id. paras. 12-16. 
The court concluded that a conditional right will not be realized if it conflicts with the rights of third parties, provided that legislation to this effect is clear and precise at the time of acquisition of the right. ${ }^{46}$ The mere fact that some protection is afforded (a right of priority) from the time of application does not necessarily mean that the property interest involved is absolute. ${ }^{47}$

The dissenting judges placed weight on the great economic value of the right conferred by trademark applications in contemporary society and recognized a protected property interest, namely the exclusive right to use the mark for named products in a certain geographic area. ${ }^{48}$ They seemed to view trademark law as wholly unsatisfactory in the modern world, since they concluded that a result that renders a valuable asset unexploitable in some markets amounts to interference with the peaceful enjoyment of one's possessions. ${ }^{49}$ The dissenters therefore concluded that the Portuguese legislation failed to strike a fair balance between the public interest sought and the individual property interest. ${ }^{50}$

In contrast, the Maori system is premised on a theory of property allocation that hinges not on the owner or object of the property but on the ownership rights to use a resource in a specific manner. ${ }^{{ }^{11}}$ Before being replaced by the British property system all land was communally owned and the community granted individual members of the community multiple usufructuary rights. ${ }^{52}$ Instead of obtaining a piece of land and all rights to it, the Maori had rights, for example, to hunt, cultivate land and pick berries. $^{53}$ The community owned the geographical space, which allocated and enforced the usufructuary rights as well as enforced its rights against other communities ${ }^{54}$ Several members thus could hold rights in the same geographical space, but they were different rights that did not encroach upon each other. ${ }^{55}$ Members were

\footnotetext{
46. Id. para. 50 .

47. Id. paras. 47,52

48. Id. para. 5 (Costa, J. \& Barreto, J., dissenting).

49. Id. (Costa, J. \& Barreto, J., dissenting).

50. Id. paras. 5-8 (Costa, J. \& Barreto, J., dissenting).

51. See Stuart Banner, Two Properties, One Land: Law and Space in NineteenthCentury New Zealand, 24 LAW \& SOC. INQUIRY 807, 811 (1999).

52. See id. at 814 .

53. See id. at 811.

54. See id. at 814 .

55. See id. at 811.
} 
encouraged to exercise their rights to their fullest extent without harming others, which put all land to its most efficient use to service the needs of the community. ${ }^{56}$ Unlike the Western system that focuses on the owner, in the Maori system what defines the scope of the right is its use.

Dressed in trademark terms, as long as the trademark is used to indicate the origin of goods or services, the owner of the mark is irrelevant for the question of ascertaining whether the mark is protected or not. In other words, the property right is alienable as long as its function in the overall system of allocation is not altered. The question is purely whether the use is legitimate in relation to the interests of third parties. Whether based on registration or use, the right exists as long as, and to the extent, it is used according to the initial allocation. Some boundaries may be encroached, which is actually desirable, in order to maximize the use of all resources. ${ }^{57}$ In the event of a conflict, whoever furnishes proof of a legitimate interest in continued use of the disputed subject matter will prevail. Regardless of the outcome of the dispute, the rights are presumed to coexist to the extent that they do not conflict with each other. When the use stops, the rights by default revert back to the community or the government pending certain circumstances set forth in legislation. ${ }^{58}$ Although the current system is arguably based upon similar logic, the contemporary emphasis on individual property rights has clearly overshadowed this premise of trademark law. ${ }^{59}$

In sum, all of the decisions referenced above treat property in land differently than other property interests and are more likely to view the property right in land as one of absolute ownership. By the same token, not all deprivations of land are illegitimate, since only some trigger the duty of compensation. All property systems recognize that property rights are not absolute; there are, however,

56. See id. at 814 .

57. See id. See generally Harold Demsetz, Toward a Theory of Property Rights, in THE AMERICAN ECONOMIC REviEW 347, 350 (Harold F. Williamson \& Gertrude Tait eds., 1967) (asserting that property rights develop to internalize externalities when the gains of internalization become larger than the cost of internalization).

58. Banner, supra note 51, at 814. After all, it is the government and not the individual rights holder that enforces the use rights of the individual against encroachment from others. See id.

59. See Mark A. Lemley, Property, Intellectual Property and Free Riding, 83 TEX L. REV. 1031, 1071 (2005). See generally Demsetz, supra note 57, at 347 (stating that an owner of property rights possesses the consent of fellowmen to allow him to act in particular ways). 
great variances between countries in which private property rights are subject to limitations in the public interest. ${ }^{60}$ Consequently, while some rights can be taken away, some rights were never granted in the first place. ${ }^{61}$ All property rights are thus inherently subject to internal as well as external limitations.

In comparison, a mobile phone consists of patented hardware, copyrighted software, and a protected design, and it is marketed under a protected trademark. All these rights exist apart from the property right in the mobile phone itself. This solution caters to needs of the contemporary dynamic community. Likewise, the Maori system optimally served the needs of their community, because the same geographic area cannot be hunted, grazed or cultivated indefinitely or it will be drained. Similarly, trademark owners need to constantly develop their trademarks to fit their products and business. The extent of the actual use therefore rarely completely coincides with the mark that is registered at any given time. However, the option of fixing the right to a physical object is not available in trademark law. While the English system that replaced the Maori system was arguably more efficient, the same system encounters its weaknesses in relation to IPRs. The physical connection distorts rather than aids the attainment of efficient allocation and forces the IPR system to race between the extremes of insufficient protection of third parties to insufficient protection of rights holders. A theory of allocation that focuses on the use, instead of the owner or object of property rights, will allow for a near optimal allocation of rights on both sides, as it is inherently flexible to the needs of the users as well as the community. ${ }^{62}$ In other words, a balance is continuously struck between competing interests both when allocating rights for use and in resolving conflicts of those rights.

What purpose, then, does the two-step deprivation analysis set forth in the South African case serve in treaty interpretation? Professor Joost Pauwelyn categorizes conflicts that arise in treaty interpretation as inherent conflicts, apparent conflicts, and genuine

60. See, e.g., Banner, supra note 51, at 811 .

61. Compare Anheuser-Busch, Inc. v. Portugal, App. No. 73049/01, para. 47 (2005), http://cmiskp.echr.coe.int/tkp197/search.asp?skin=hudoc-en (search for application number "73049/01", then follow the link for the Oct. 11, 2005 decision) (last visited Apr. 22, 2007) with J.A. Pye (Oxford) Ltd. v. United Kingdom, App. No. 44302/02, 43 Eur. H.R. Rep. 3, 65 (2006) (Maruste, Garlicki \& Borrego Borrego, JJ., dissenting).

62. See also Lemley, supra note 59, at 1048-50, 1071. 
conflicts. $^{63}$ In matters of international trademark law, a false conflict might arise when trademark rights are impacted by legislation. Careful scrutiny, however, reveals that the trademark owner does not have a legitimate property interest in the subject matter that has allegedly been deprived. The majority in Anheuser-Busch v. Portugal reached this conclusion. Likewise, the legislation might not legitimately allow a third party to encroach upon the contested subject matter and hence the apparent conflict of norms was an illusion.

Unlike false conflicts where the decision turns on the lack of a protected interest on either side, a true apparent conflict requires the decision-maker to consider the arbitrariness of a deprivation in light of the public interest, since both parties have legitimate interests in the contested subject matter. Balancing of interests is required and guidance is sought from the contextual framework of the conflicting provisions as well as the general rules of treaty interpretation. A genuine conflict of norms, where the object and purpose of the agreements or provisions in question undeniably conflict, cannot be resolved through treaty interpretation, but can only be resolved by the legislature. ${ }^{64}$

\section{B. The Contents and "Meaning" of an Exclusive Right}

As mentioned above, the term "property" in itself bears no legal significance. The significant aspects of property lie in the rights it confers upon its holder-a bundle of rights. The traditional bundle includes (1) the right to lawfully use the property in a certain way, (2) the right to alienate (i.e., the right to sell, lend, lease, and use as collateral, and (3) the right to exclude others ${ }^{65}$ On one hand, a property right is a right against the world, since it confers enforceable rights to something on the owner. On the other hand, the contents of the rights in the bundle differs depending on whom it is asserted against based on the duties of ownership conferred on the owner in the initial allocation. ${ }^{66}$ laws)

63. See generally PAUWELYN, supra note 3, at 171-87 (describing different conflicts of 64. agreements contain explicit conflicts clauses, (2) the newer agreement governs (lex posterior), (3) the specialized rule governs (lex specialis), or (4) the aggrieved party is compensated).

65. See, e.g., WALDRON, supra note 15, at 27-28.

66. See, e.g., id. 
Neither is the bundle of rights static or constant in effect or character, since each right itself confers the right on the owner to change the relationship. In this sense the property right is defined by contracts between the owner and others. However, there are some "inherent defects" in all titles that the owner does not have the power to correct. We focus on those next.

The property right is necessarily defined by its object. Unlike a plot of land or physical object, defining the object of intellectual property rights is notoriously difficult. ${ }^{67}$ Most other intangible interests can be, at least conceptually, tied to some tangible form of property, which in turn can be contrasted against the right. For example, a bank holds a mortgage on a house only insofar as the debt has not been paid, and a shareholder's interest is defined by the existence and success of the company as well as the interests of other shareholders. No one, generally, has a property right in the subject matter from which a trademark is created; it is taken from the pool of collective resources. At the same time, the object of the right is distinct from the property right in the paper it is printed on, the Web site that displays it, or the goods to which it is affixed. Any attempt to contrast it with a tangible resource leads to a misleading result, since they are not connected in the traditional property law sense. ${ }^{68}$

"Possession" is another traditional approach to defining a property right. It occurs when the resource is taken out of the common pool. ${ }^{69}$ A landowner gains ownership by marking the boundaries of her plot of land and claims ownership to wild horses by capturing them and fencing them in. The trademark owner claims a similar right when he initially uses the mark in commerce. If no one else is using the same mark on the same goods, it is quite easy for the public to accept the capture of a specific "plot" on the market. ${ }^{70}$ However, much like a neighbor who is likely to object when the landowner tries to expand the boundaries of her property-or the community, when one family captures all the

67. See Robin Jacob \& Daniel Alexander, A Guidebook to InTEllectual PROPERTY: PATENTS, TRADEMARKS, COPYRIGHT AND DESIGNS 4-5 (Sweet \& Maxwell 1993) (1970).

68. See Lemley, supra note 59, at 1033.

69. See Carol M. Rose, Possession as the Origin of Property, in PERSPECTIVES IN PROPERTY LAW 181 (Ellickson et al. eds., 2002) (describing the common law notion of "possession" or "occupancy" as the origin of property).

70. See generally Dinwoodie \& Janis, supra note 7, at 17-18 (stating the importance of "use" in the establishment of trademark rights). 
horses-problems arise when the trademark owner adopts an expansive interpretation of the right to exclude others. If these conflicts were decided by whoever has possession, the "encroacher" would naturally have the upper hand. ${ }^{7}$ However, in a society with scarce resources, these conflicts are generally decided by scrutinizing the original allocation of property rights for inherent defects in title. ${ }^{72}$

In other words, the trademark right is defined by weighing it against the public interest against allocating any right (to the contested subject matter) to begin with. The object of contention is separate from the initial allocation and does not affect the original grant. In this sense each infringement action turns on whether or not the trademark owner has a legitimate expectation in the property interest sought. After all, a property right only has value if it can be enforced against others. ${ }^{73}$

Legitimacy is derived from the initial grant as set forth by trademark legislation. Article 16.1 of the TRIPS Agreement affords the trademark owner the following rights:

The owner of a registered trademark shall have the exclusive right to prevent all third parties not having the owner's consent from using in the course of trade identical or similar signs for goods or services which are identical or similar to those in respect of which the trademark is registered where such use would result in a likelihood of confusion. In case of the use of an identical sign for identical goods or services, a likelihood of confusion shall be presumed. The rights described above shall not prejudice any existing prior rights, nor shall they affect the possibility of Members making rights available on the basis of use.

The international minimum standard of trademark protection only applies to registered marks even though Member States are allowed to afford additional protection based on use of a mark. A

71. The encroachment on a trademark is similar to a claim of adverse possession. See, e.g., Carrier, supra note 11, at 58-59 (describing how adverse possessors were favored by the law as a means to encourage productive use of land).

72. For example, John Locke's theory on allocation views property rights as an extension of labor and presumes that it is immoral to take too much. See JOHN LOCKE, Two Treatises of Government, 300-02 (Peter Laslett ed., Cambridge Univ. Press 1988) (1690); see also Rose, supra note 69, at 180.

73. See Demsetz, supra note 57 , at 347,355 . Ownership has no value if anyone can take the object of ownership from its owner or the owner has no conceivable means of enforcing his right. See id. 
mark that has become well-known through extended use (after registration) is awarded extended protection. ${ }^{74}$ The initial grant of an exclusive right is thus subject to four inherent defects in title; the owner only can prevent a third party from using a mark (1) in commerce, (2) as a trade or service mark, (3) on identical or similar goods, and (4) where the use results in a likelihood of confusion. ${ }^{75}$ The chosen language clearly indicates that the factors are cumulative.

In addition to affording a limited right, the TRIPS Agreement acknowledges that the trademark right confers certain rights and duties on the trademark owner. Member States may impose a requirement of use (and most do) and renewal in order to maintain the registration, but a trademark registration shall, in principle, be renewable indefinitely. ${ }^{76}$ The use of a trademark shall not be unjustifiably burdened with special requirements, nor can it ever be subject to a compulsory license. "In addition, licensing and assignment of a trademark shall be possible with or without transfer of the business to which the trademark belongs. ${ }^{78}$

\section{The Derogation Allowed from AfForded Rights UNDER ARTICLE 17}

\section{A. Introduction}

The last section concerned the inherent constraints on the afforded right. This section concerns the right of the government to regulate in ways that affect the exercise of trademark rights. The distinction between allocation and exercise of a right is not necessarily clear in practice. However, national laws generally acknowledge this distinction through evidentiary rules. Since registration serves as notice on third parties the legitimacy of the trademark owner's interest is presumed for what is registered. ${ }^{79}$ The trademark owner must prove his entitlement to any additional protection. Only when the trademark owner has a legitimate interest in the exclusive use of a mark does the defendant's duty to furnish evidence in his defense kick in.

\footnotetext{
74. TRIPS Agreement, supra note 1, art. 16, para. 3.

75. Id. art. 16 , paras. 1,3

76. Id. arts. $18-19$.

77. Id. arts. $20-21$.

78. Id. art. 21.

79. See id. art. 16 .
} 
The logic of this analytical structure operates with a twist on the international level. Under the TRIPS Agreement, Member States are only mandated to provide minimum protection to trademark owners, unless the principles of national treatment or most favored nation are violated. ${ }^{80}$ Hence, additional protection is not mandated but a choice which in turn can trigger certain duties, namely that of equal treatment. The paramount question of law when considering the arbitrariness of the deprivation remains whether or not the Member State is in violation of its international obligation to provide a minimum standard of protection for trademarks. Like the question in the property cases above, the inquiry includes two parts: (1) is a legitimate property interest at stake? and (2) is the deprivation arbitrary or illegitimate?

Article 17 of the TRIPS Agreement reads as follows: "Members may provide limited exceptions to the rights conferred by a trademark, such as fair use of descriptive terms, provided that such exceptions take account of the legitimate interests of the trademark owner and of third parties."

Hence, the exclusive right afforded in Article 16(1) can be subject to limited exceptions. In other words, even if all four elements of Article 16 (1) are satisfied and a mark is used in commerce on identical or similar goods in a way that causes a likelihood of confusion, the use may nonetheless be lawful.

B. European Communities-Protection of Trademarks and Geographical Indications for Agricultural Products and Foodstuffs

1. Does Article 24 of the TRIPS Agreement Provide an Exception to Trademark Rights?

The proposed conceptual structure of international trademark law is useful in assessing the above-mentioned Panel Report regarding the protection of trademarks and GIs under the TRIPS Agreement. The GI-report interpreted Articles 24.5, 24.3, and 17 of the TRIPS Agreement, since the European Communities raised them as a defense of its legislation regarding $\mathrm{GIs},{ }^{81}$ in response to

80. Id. arts. 3-4.

81. Compare Council Regulation 2081/92, arts. 10-14, 1992 O.J. (L 208) 1, 1-8 (EC), with TRIPS Agreement, supra note 1, arts. 17, 24. 
complaints by Australia and the United States that the EC violated Article 16(1) of the TRIPS Agreement. ${ }^{82}$

The EC legislation confers an implied right to use a GI in relation to the relevant products upon registration. ${ }^{83}$ Article 14(2) of the regulation allows for the continued use of trademarks that were registered prior to the registration of a GI. In addition, Article 14(3) of the regulation provides that the registration of a GI shall be refused if it leads to a likelihood of confusion with an earlier trademark. Notwithstanding Article 14(3) of the regulation, the main argument set forth by the complainants is that the trademark rights afforded under Article 16(1) of the TRIPS Agreement cannot be fully exercised against a person who uses a registered GI in accordance with the right conferred by registration. ${ }^{84}$ The EC, on the other hand, claims that Article 14(2) is necessary to implement its obligations under Article 24 of the TRIPS Agreement. ${ }^{85}$

Article 24 sets forth the minimum standard of GI protection in the TRIPS Agreement. Article 24.5 limits the reach of GI protection that a Member State may afford in relation to existing trademarks, the exclusive rights to which have been acquired prior to the protection of the GI in its home country. The Panel rejected the argument that Article 24.5 is exhaustive in the sense that Member States under the TRIPS agreement are free to limit the use of trademarks that have been acquired after a GI is protected in its home country. ${ }^{86}$ Likewise the Panel rejected the argument that a Member State is obligated under Article 24 to afford such GI protection. ${ }^{87}$

The Panel concluded that Article 24.5 creates an exception to GI protection mandated by the TRIPS Agreement and also that, notwithstanding Article 24, Members States are required under Article 16(1) to make available the right to exclude certain uses, which includes uses as a GI. ${ }^{88}$ The GI-Panel arrived at this conclusion by way of interpreting the words "when implementing

82. EC Panel Report, supra note 6, II 7.627-.686.

83. Traditionally, however, this has been interpreted in civil law countries as granting an implied right to use. See EC Panel Report, supra note 6, 9I 7.521. Compare EC Panel Report, supra note 6, II 7.522, with Council Regulation 2081/92, art. 13.

84. EC Panel Report, supra note 6, II 7.531.

85. Id. II 7.525 .

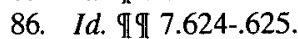

87. See id. पा Tा 7.617-.619.

88. Id. II 7.625 . 
this section" in Articles 24.3 and 24.5 to render the conferred obligations inapplicable in relation to other obligations in the TRIPS Agreement. Since the obligation to afford trademark protection is found in section 2 of the TRIPS agreement (without a similar qualifier), any obligation of coexistence cannot be presumed. ${ }^{89}$ The GI-Panel concluded that they refuse to adopt an approach to treaty interpretation, which is not supported by the ordinary meaning of its terms in their context. ${ }^{90}$

\section{Exceptions under Article 17 of the TRIPS Agreement}

According to Article 17 the GI-Panel recognized two elements that the national legislation must satisfy: (1) the exceptions must be limited and (2) must take into account the legitimate interests of the trademark owner and of third parties. Any interpretation of either element that excludes the example "fair use of descriptive terms" is necessarily incorrect."

The GI-Panel relied upon the interpretation by two previous panels regarding exceptions to copyrights and patents. ${ }^{92}$ However, there are some significant differences between these provisions, requiring interpretation of Article 17 "according to its own terms."

[U]nlike the other provisions Article 17 contains no reference to 'conflict with a [or the] normal exploitation,' no reference to 'unreasonable prejudice to the legitimate interests' of the right holder or owner, and it not only refers to the legitimate interests of third parties but treats them on par with those of the right holder. ${ }^{93}$

Article 17 clearly permits exceptions that are not applicable to other intellectual property rights. ${ }^{94}$

In ascertaining the meaning of the term "limited exceptions" the GI-Panel concluded that the issue is whether the exception to

89. Id. II I $7.606,7.632$.

90. Id. \ 7.624 .

91. Id. I 7.648 .

92. Panel Report, Canada-Patent Protection of Pharmaceutical Products, WT/DS114/R (Mar. 17, 2000) [hereinafter Canada Patent Panel Report] (interpreting exceptions to patent regulations under article 30 of the TRIPS Agreement); Panel Report, United States - Section 110(5) of the U.S. Copyright Act, 26-29, WT/DS160/R (June 15, 2000) [hereinafter U.S. Copyright Panel Report] (interpreting exceptions to copyright regulations under article thirteen of the TRIPS Agreement).

93. EC Panel Report, supra note 6, I1 7.649.

94. Id. T 7.649. 
the rights conferred by a trademark is narrow. ${ }^{95}$ Exceptions may apply to (1) the category of third parties, (2) the identity or similarity of the marks or goods, (3) the degree of likelihood of confusion, (4) a combination of the above, or (5) in some other way, as long as they are limited. The Panel noted that

Fair use of descriptive terms is not limited in terms of the number of third parties who may benefit, nor in terms of the quantity of goods or services with respect to which they use the descriptive terms, although implicitly it only applies to those third parties who would use those terms in the course of trade and to those foods or services which those terms describe. ${ }^{96}$

Still, it satisfies the elements of Article 17.

The number of trademarks or trademark owners affected is irrelevant. ${ }^{97}$ Thus, the focus remains on the impact on the rights of the trademark owner. Although the quantity of goods that benefit from an exception might indirectly curtail the exercise of the right to exclude others, preventing acts of making, selling or importing goods are not rights conferred by a trademark..$^{98}$ The trademark right only entails the right to prevent confusing uses. ${ }^{99}$ On the other hand, the GI-Panel noted that "GI registration does not confer a positive right to use any other signs or combinations of signs nor to use the name in any linguistic versions." ${ }^{100}$ Hence, the trademark owner's rights are not limited against such uses. Likewise, the GI regulation recognizes a ground for refusal of registration based on an earlier trademark. ${ }^{101}$ Therefore, the trademark owner's right to exclude confusing uses is not completely diminished even against the GI applicant.

\section{Legitimate interests}

Following a contextual approach, the GI-Panel concluded that the legitimate interests of the trademark owner must be something different from the full enjoyment of the rights conferred

95. Id. II 7.650. See Canada Patent Panel Report, supra note 92, II 7.30 (noting that relevant inquiry focuses on exceptions to the rights conferred, not to a set of trademarks or trademark owners).

96. EC Panel Report, supra note 6, II 7.654.

97. Id. I 7.655 .

98. Id. \I 7.656 .

99. Id.

100. Id. \ 7.657 .

101. Id. II 7.658 . 
by a trademark..$^{102}$ Equally, the legitimate interests of third parties must be something more than simple enjoyment of their legal rights. ${ }^{103}$ Citing Canada-Pharmaceuticals Patents, the GI-Panel concluded that the provision calls "for protection of interests that are 'justifiable' in the sense that they are supported by relevant public policies and other social norms." 104

The GI-Panel referred to the WTO Members' shared understandings of the policies and norms relevant to trademarks when concluding that the protected function of trademarks is the ability to distinguish goods and services from those of other companies in the course of trade ${ }^{105}$ While it is in the legitimate interest of the trademark owner to receive protection of the source identifying function of its trademark, protection is not absolute. ${ }^{106}$ Compared to Articles 13, 26.2, and 30, which refer to "unreasonable prejudice," Article 17 only requires that exceptions "take account" of the legitimate interests of the owner. ${ }^{107}$ According to the GI-Panel the chosen wording suggests that less protection is required for the legitimate interests of the trademark owner. ${ }^{108}$ This reading also corresponds with the absence of specific reference to the rights of third parties in Articles 13, 26.2, and 30.

The GI-Panel further notes that the relevant third parties for the purposes of Article 17 include both consumers and persons using a geographical indication. ${ }^{109}$ After all, the legitimacy of the interests of GI users is reflected in the TRIPS Agreement itself. ${ }^{110}$ The Panel defines the legitimate interest of GI owners by contrasting Articles 22 and 23 of the TRIPS Agreement, in which the legal protection of GIs are described.".11 Furthermore, the GIPanel analogizes to the example in Article 17 concluding that GI protection serves a similar purpose and is therefore legitimate. ${ }^{112}$

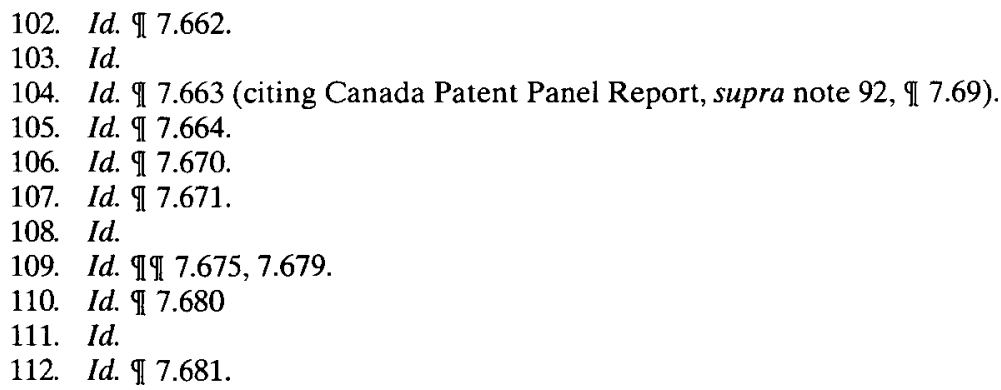


IV. The ConteXtual and Structural Framework of THE TRIPS AGREEMENT

\section{A. The Framework of International Law and International Trade}

The TRIPS Agreement is part of a larger framework of treaties that regulate international trade under the auspices of the WTO.$^{113}$ The underlying purpose of the TRIPS Agreement is to reduce distortions and impediments to international trade. The means employed to reach this goal are securing effective and adequate protection of IPRs while ensuring that the measures and procedures to enforce IPRs do not themselves become barriers to legitimate trade. ${ }^{114}$ According to Article 7, the objective of the TRIPS Agreement is to "contribute to the promotion of technological innovation ... to the mutual advantage of producers and users ... in a manner conducive to the social and economic welfare, and to a balance of rights and obligations." Furthermore, Article 8 shows deference to Member States in formulating and amending laws and adopting measures necessary to promote the public interest in sectors of vital importance to their socio-economic and technological development. ${ }^{16}$ With the objective and purpose of the TRIPS Agreement in mind the Member States adopted the following international obligation:

\section{Article 1}

Nature and Scope of Obligations

1. Members shall give effect to the provisions of this Agreement. Members may, but shall not be obliged to, implement in their law more extensive protection than is required by this Agreement, provided that such protection does not contravene the provisions of this Agreement. Members shall be free to determine the appropriate method of implementing the provisions of this Agreement within their own legal system and practice.

Adopting minimum standards of protection follows the traditional format of international agreements. After all, it is notoriously difficult to reach consensus on an adequate level of protection between more than 150 different legal systems while

113. See TRIPS Agreement, supra note 1, annexes 1A-1C, 2.

114. Id., pmbl.

115. Id. art. 7.

116. Id. art. 8. 
maintaining a level that has any practical effect. ${ }^{117}$ In addition, great deference is shown to the Member States in implementing the provisions of the treaty, both in the means chosen as well as in the level of protection in practice, provided that it is higher than the minimum level of protection. ${ }^{118}$ Lastly, it should be noted that while Member States agreed on the issue of granting protection, they excluded from consideration the issue of when the rights afforded under the TRIPS Agreement are exhausted. ${ }^{119}$

To give added force to the international trade rules, the Understanding on Rules and Procedures Governing the Settlement of Disputes ("DSU") was annexed to the agreement establishing the WTO, to govern all disputes between Member States. ${ }^{120}$ DSU Article 3.2 states that the WTO dispute settlement system "serves to preserve the rights and obligations of Members under the ... agreements, and to clarify the existing provisions of those agreements in accordance with customary rules of interpretation of public international law." ${ }^{121}$ Recommendations and rulings cannot add or diminish those rights and obligations. ${ }^{122}$ In United States-Standards for Reformulated and Conventional Gasoline, the Appellate Body confirmed that Articles 31 and 32 of the Vienna Convention on the Law of Treaties incorporates the customary rules of public international law. ${ }^{123}$

Customary rules of public international law mandate that "a treaty shall be interpreted in good faith in accordance with the ordinary meaning to be given to the terms of the treaty in their

117. See Rubens Ricupero, Rebuilding Confidence in the Multilateral Trading System: Closing the "Legitimacy Gap," in THE ROLE OF THE WORLD TRADE ORGANIZATION IN GLOBAL GOVERNANCE, supra note 2, at 37-38 (describing problems facing the WTO despite adoption of minimum standards).

118. JACKSON, supra note 3 , at 134 .

119. TRIPS Agreement, supra note 1, art. 6 (stating the principles of national treatment and most-favored nation cannot be invoked in dispute settlement regarding the issue of exhaustion of intellectual property rights).

120. See Understanding on Rules and Procedures Governing the Settlement of Disputes, Apr. 15, 1994, Marrakesh Agreement Establishing the World Trade Organization, Annex 2, Legal Instruments-Results of the Uruguay Round, 33 I.L.M. 122 (1994) [hereinafter DSU].

121. Id. art. $3(2)$.

122. See id. art. 3(5).

123. Appellate Body Report, United States-Standards for Reformulated and Conventional Gasoline, 15-16, WT/DS2/AB/R (Apr. 29, 1996) [hereinafter U.S. Standards Appellate Body Report]. 
context and in the light of its objective and purpose."124 The relevant context is composed of the text, preamble, annexes, and any other agreement relating to the treaty between the same parties. ${ }^{125}$ Recourse to supplementary means of interpretation is only allowed when the contextual interpretation leaves the meaning ambiguous or leads to a manifestly absurd or unreasonable result. ${ }^{126}$ Customary international law thus provides different tools of interpretation for different conflicts within international jurisdiction and also draws the line between national and international jurisdiction. ${ }^{127}$

The requirement of good faith interpretation has traditionally been construed to mandate narrow interpretation of treaty provisions and exclude $e$ contrario conclusions regarding the intentions of Member States in international law. ${ }^{128}$ However, in light of the objective and purpose of the treaty, the contextual approach secures an interpretation that gives all provisions some effect. The universally recognized principle of pacta sunt servanda mandates that the text of the treaty is binding upon the parties and cannot be watered down by subsequent interpretation..$^{129}$

In sum, international law operates much like contract law, which is premised on the principles of contractual freedom on the one hand and strict (legal or diplomatic) enforcement of contractual obligations on the other. Commitment to the system of international law, however, does not allow for parties to opt out of all of their obligations. Because there is no hierarchy of treaties, the unity of international law is what lends legitimacy to international law. Unless a Member State explicitly contracts out of an international obligation, it is presumptively bound by that obligation in all other contractual relationships. ${ }^{130}$

124. Vienna Convention on the Law of Treaties art. 31.1, May 23, 1969, 21 U.S.T. 77, 1155 U.N.T.S. 331 [hereinafter Vienna Convention]; see U.S. Shrimp Appellate Body Report, supra note 8, at $\mathbb{I}$ II 104, 111.

125. Vienna Convention, supra note 124, art. 31.

126. Id. art. 32.

127. See PAUWELYN, supra note 3, at 441-43.

128. See generally id. at 465 .

129. See Vienna Convention, supra note 124, pmbl. (noting the principles of free consent and good faith and pacta sunt servanda are universally recognized).

130. See PAuWelyn, supra note 3, at 461-67 (citing Panel Report, Korea Government Procurement, II 7.101 n.755, WT/DS163/R (May 1, 2000)). 


\section{B. The Evolution of International Norms and the Status of WTO Panel Reports}

The function of WTO panels is to assist the Dispute Settlement Body ("DSB") by making an objective assessment of the facts at hand and their applicability and conformity with the relevant agreements. ${ }^{131}$ Nowadays, WTO panel reports as well as Appellate Body reports are semi-automatically adopted by the DSB and subsequently obtain the status of an authoritative statement of international law. ${ }^{132}$ How then should the WTO panel reports be interpreted and what reach should the rulings be given?

This section will ascertain the binding force or effect of a panel ruling as a contribution to the body of international trade law. ${ }^{133}$ According to the DSU the purpose of the dispute settlement system and hence the rulings set forth by it is to provide "security and predictability to the multilateral trading system." ${ }^{134}$ Much like any other decision-making body in a rule-oriented (as opposed to policy-based) system, the WTO system cannot be successful unless three goals are met: the system must be viewed by the Member States as (1) just, (2) credible, and (3) efficient. ${ }^{135}$ All panel rulings and rationales are thus subject to intense scrutiny. Consequently, WTO panels have sought to adopt an analytical, objective, and nonpolitical procedure that is firmly anchored in principles of international law. ${ }^{136}$ While clearly aware of their larger audience in aspects of procedure and form, it seems unclear what substantive reach (source value) is to be given to the rulings of WTO panels.

Due to the above-mentioned concerns the approach of WTO panels is necessarily formalistic in the sense that panels will rely heavily on treaty text as well as perceived neutral sources of interpretation. Certain WTO panels have, however, taken a highly formalistic, almost exclusively literal approach, to interpretation of

131. DSU, supra note 120 , art. 11.

132. DSU, supra note 120 , arts. 16(4), 17(14).

133. John H. Jackson, The WTO Dispute Settlement UnderstandingMisunderstandings on the Nature of Legal Obligation, 91 AM. J. INT'L L. 60 (1997); Warren F. Schwartz \& Alan O. Sykes, The Economic Structure of Renegotiation and Dispute Resolution in the World Trade Organization, 31 J. LEGAL STUD. 179 (2002). See generally Judith Hippler Bello, Commentary, The WTO Dispute Settlement Understanding: Less is More, 90 AM. J. INT'L L. 416 (1996) (discussing to what extent the WTO's rules enforcement affects Members' obligation to comply in practice).

134. DSU, supra note 120 , art. 3(2).

135. JACKSON, supra note 3 , at $134,161$.

136. Id. at 134,160 . 
the provisions of the TRIPS Agreement. ${ }^{137}$ What weight should these reports or statements have as a source of law?

In Japan-Taxes on Alcoholic Beverages the Appellate Body considered whether prior reports constitute "subsequent practice" for purposes of treaty interpretation within the meaning of Article 31 of the Vienna Convention. ${ }^{138}$ The Appellate Body held that the decision to adopt a panel report neither constitutes agreement on the reasoning by that panel, nor elevates the report to a binding source of law on subsequent panels. ${ }^{139}$ Reports are only binding with respect to resolving a particular dispute between the parties. Nevertheless, panel reports should be taken into account because they may create legitimate expectations among Member States. ${ }^{140}$

Furthermore, the correct interpretative approach under the Vienna Convention follows the general principle of effectiveness of treaty interpretation..$^{141}$ Although the correct approach to any provision is textual, interpretation should always rest on the objective and purpose of provisions, i.e. respecting the words while not diminishing the meaning of words actually used in other provisions. Any provision should be read in light of the broad and fundamental purpose of that provision that gives meaning and effect to all of its terms..$^{142}$

The Appellate Body has further elaborated on rules of treaty interpretation in US-Import Prohibition of Certain Shrimp and Shrimp Products. ${ }^{143}$ Any measure that is subject to a violation complaint ${ }^{144}$ should be scrutinized in light of its meaning and effect

137. Canada Patent Panel Report, supra note 92 (interpreting exceptions to patent regulations under article thirty of the TRIPS Agreement); U.S. Copyright Panel Report, supra note 92 (interpreting exceptions to copyright regulations under article thirteen of the TRIPS Agreement); see EC Panel Report, supra note 6.

138. See Appellate Body Report, Japan - Taxes on Alcoholic Beverages, WT/DS8/AB/R, WT/DS10/AB/R, WT/DS11/AB/R (Oct. 4, 1996) [hereinafter Japan Taxes Appellate Body Report].

139. See id. The Appellate body relied on Article IX(2) of the WTO Agreement as well as DSU article 3.9, which retains the exclusive authority to issue definite treaty interpretations to the General Ministerial Council by a three-fourths majority vote. Id.

140. See id.

141. See id.

142. See id.

143. U.S. Shrimp Appellate Body Report, supra note 8

144. At present, violation complaints are the only form of complaint under the TRIPS agreement, since the TRIPS Council has been unable to agree on the permissibility of non-violation complaints. See, e.g., Developing Country Group, TRIPS and Public Health, If 42 (World Trade Org., Working Paper, June 20, 2001), available at http://www.wto.org/ english/tratop_e/trips_e/paper_develop_w296_e.htm (discussing access to medicine); see 
in relation to the relevant international obligations of the MemberState in question, not with a focus on the nature or design of the measure itself. ${ }^{145}$ Furthermore, maintaining the multilateral trading system is not a right or obligation per se, instead each provision should be reviewed in light of the object and purpose of the provision itself. Thus, generally testing a measure for consistency with the object and purpose of the treaty exceeds the jurisdiction of the panels. ${ }^{146}$ Nevertheless, the result of the interpretative approach must lead to a test or standard that is justifiable under the agreement. ${ }^{147}$ Consequently, absent express wording on point, terms of the treaty must nonetheless be read in light of contemporary concerns among the Member States as expressed, e.g., in the preamble of the agreement. ${ }^{148}$

Finally, the Appellate Body has expressly stated that Member States "should not be assumed ... to have continued previous protection or discrimination through the adoption of a new measure", since this would amount to a presumption of bad faith that is inconsistent with the general nature of international law. ${ }^{149}$ However, the policy goal of a measure, no matter how noble, cannot provide its justification, if it does not meet the general requirements for an exemption. ${ }^{130}$ Total deference to Member States cannot ensure an objective assessment under Article 3.2 of the DSU. ${ }^{151}$

In any search for a meaning of a treaty, treaty interpretation should be seen as a tool for conflict avoidance. ${ }^{152}$ As mentioned above, conflicts can generally be categorized as false conflicts, true

also GRAEME B. DINWOODIE ET AL., INTERNATIONAL INTELLECTUAL PROPERTY LAW AND POLICY 847-48 (2001) (noting the fact that non-violation complaints are not available also constrains panel jurisdiction in interpreting the TRIPS Agreement).

145. U.S. Shrimp Appellate Body Report, supra note 8, $\mathbb{I} \mathbb{T}$ 114-15.

146. Id. I 116.

147. Id. I 121.

148. Id. I 129.

149. See Appellate Body Report, Chile - Taxes on Alcoholic Beverages, If 74, WT/DS87/AB/R, WT/DS110/AB/R (Dec. 13, 1999).

150. U.S. Shrimp Appellate Body Report, supra note 8, भI 149.

151. Cf. David Palmeter \& Petros C. Mavroidis, Dispute Settlement in the World Trade Organization Practice and Procedure 86 (1999) (citing Panel Report, United States - Restrictions on Import of Cotton and Man-Made Fibre Underwear, II 7.10, WT/DS24/R (Nov. 8, 1996) (adopted Feb. 10, 1997) (stating that a "policy of total deference to the findings of the national authorities could not ensure an 'objective assessment' as envisioned by Article 11").

152. See PAUWELYN, supra note 3, at 244-45. 
apparent conflicts, and genuine conflicts. ${ }^{153}$ While the former two can be solved by recourse to treaty interpretation, genuine conflicts are outside the jurisdiction of WTO panels. ${ }^{1.54}$ However, no conflict can even hypothetically exist if (1) the language of the provision in question is not broad or ambiguous enough to allow input from other provisions regarding its meaning and (2) the second rule in question does not express anything about what the first one means. ${ }^{155}$ This rule stems from the prohibition under customary international law of interpretations contra legem. ${ }^{156}$

False conflicts can be solved by reference to the principle of efficient treaty interpretation. The provisions are interpreted in good faith in light of their objective and purpose. No meaning can be given to the provisions that would be contrary to their "letter and spirit. ${ }^{1157}$ Hence, words cannot be interpreted into nor out of a treaty provision. ${ }^{158}$ Efficient treaty interpretation is only permissible to the extent that a harmonious result can be reached. Whether the result is in favor of the first or second provision is irrelevant.

True conflicts, on the other hand, require reference to norms outside the text of the treaty in order to determine whether the solution of the conflict is within international jurisdiction. ${ }^{1.59}$ True apparent conflicts generally are within international jurisdiction (although decision-making authority can have been withheld from the WTO panels). However, genuine conflicts can only be resolved by way of amendment of the treaty. ${ }^{160}$

\section{Evaluation OF THE GI PANEL REPORT IN LIGHT OF THE Proposed ANALyTICAL FramewORK}

The GI-Panel arguably was in a difficult position, since the collision between the interests of trademark owners and GI

153. See discussion supra note 63.

154. PAUWELYN, supra note 3, at 272.

155. Id. at 245 .

156. See id. Conflicts (false, apparent or genuine) only arise, if a bona fide interpretation of the text of the allegedly conflicting provisions appears to create a conflict. See id.

157. See id. at 248; U.S. Standards Appellate Body Report, supra note 123, at 23; Japan Taxes Appellate Body Report, supra note 138, at 12.

158. See PAUWELYN, supra note 3, at 249.

159. See generally id. at 251-68 (discussing how the Appellate Body has viewed articles 31 and 32 of the Vienna Convention and norms of international law in preventing genuine conflicts from arising).

160. See PAUWELYN, supra note 3, at 248-49, 272. 
owners are one of the most contested issues in the international arena. In its final analysis, the GI-Panel correctly focused the analysis on the rights afforded and the effect of the limitation on the underlying property interest. However, the GI-Panel failed to distinguish the rights afforded from those withheld in relation to GI holders ${ }^{161}$ and consequently failed to distinguish between deprivations per se (exceptions that should not be analyzed under Article 17 because no legitimate property interest is deprived) and arbitrary or illegitimate deprivations (exceptions that should be analyzed under Article 17).

In other words, the GI-Panel should have asked whether trademark owners have a legitimate interest in excluding GI users and weighed this interest against the legitimacy of the interest of GI users in receiving protection. At this juncture, the GI-Panel should have distinguished between the legitimate interests of existing trademark owners and prospective trademark owners in the relevant market and accordingly weighed how the regulation protected their respective interests against existing and prospective GI users. After all, sweeping generalizations regarding the legitimate interest of the trademark owner as well as a GI owner are unadvisable since they, like all property rights, vary according to whom it is asserted against. The distinction is supported by the text of the treaty since Article 24.5 , the exception to GI protection in favor of trademark owners, only applies to existing trademark owners in relation to prospective GI users. A reading that does not make the distinction renders Article 24.5 meaningless, a conclusion that can never be supported under the international rules on treaty interpretation..$^{162}$

Secondly, Article 17 clearly includes a static dimension, i.e. Member States are allowed to maintain existing limitations on trademark rights. The question to what extent Member States are

161. The Panel treated this discussion as non-relational in the sense that it focused on what interests the trademark owner had in protecting, as opposed to legitimate interests and what interest GI users had in limiting the trademark owner's right. The Panel did not take the necessary third step; i.e. Article 17 expressly mandates that legitimacy of interests be assessed in relation to the interests of third parties. This is not meant to say that the Panel should not have weighed the effect of the "deprivation" in relation to the rights the trademark owner retained despite GIs. Indeed, the degree of "deprivation" is an important component when assessing the fairness of the balance struck.

162. U.S. Standards Appellate Body Report, supra note 123, at 23. 
allowed to introduce new exceptions to trademark rights under the TRIPS Agreement is arguably more controversial. ${ }^{163}$

Despite the adopted contextual approach, the GI-Panel arguably treated Article 17 as well as the TRIPS Agreement itself as only including a static dimension, i.e. a fixed allocation of rights and duties. The GI-Panel took the standard of protection expressed in the TRIPS Agreement as the starting point for its analysis when evaluating whether the exceptions were limited and whether the interests of the parties were legitimate. Hence, the limited scope of the exception was ascertained by contrasting it to the international minimum standard of protection, and the legitimacy of interests of third parties was ascertained by equating the interest to the international minimum standard of protection and subjecting it to the provision of Article 17.

Member States, however, are entitled to grant more protection for IPRs than the international minimum standard set forth in the TRIPS Agreement. ${ }^{164}$ Most Western nations do, and the Member States of the European Community grant higher levels of protection to both trademarks and GIs than mandated by the TRIPS Agreement. In other words, while the TRIPS Agreement mandates that Member States afford some level of protection for trademarks as well as GIs, an e contrario conclusion is not permissible under international law: the TRIPS Agreement does not mandate protection only to the extent afforded by its provisions.

163. According to the GI-Panel's reading of Article 24, this issue is and is not governed by international obligations. See EC Panel Report, supra note 6, III 7.634-.636. The TRIPS Agreement mandates protection of trademarks and GIs, but only insofar as the latter does not encroach on the exercise of the former. See $i d$. The GI-Panel thus created a hierarchy of IPRs and seemed to treat the issue of compliance as one of fact, not of law, when concluding that the EC regulation did not impact the exercise of trademark rights so as to render the exception too broad to qualify under Article 17. See id. $\mathbb{1}$ T 7.644-.688. The Panel should as a matter of law (compare to Article 1.1) have shown deference to the Member State and started from the factual presumption that the measure, at least in part, was mandated by Article 24 of TRIPS. After all, the European Community had not previously offered any GI protection under its post-TRIPS regulations prior to January 1 , 1995. See id. If 7.636. It is at least questionable, whether the GI-Panel had jurisdiction to interpret the TRIPS Agreement so as to alter the delicate balance struck in the negotiations that led to TRIPS. Under international law genuine conflicts cannot be solved by way of interpretation. See PAUWELYN, supra note 3, at 272.

164. See TRIPS Agreement, supra note 1, art. 1.1. Even regarding GI protection, the TRIPS Agreement can hardly objectively be read as having concluded that, for example, France and Italy agreed to lower their existing GI protection based on their obligation under Article 16(1). 
The GI-Panel treated the minimum standard of protection afforded to GIs under the TRIPS Agreement as a "ceiling" in the sense that it only recognized these interests as legitimate, and analytically subordinated these interests to those of trademark owners by viewing minimum GI protection as an exception. The GI-Panel, as panels before it had done regarding copyright and patents, used a standard similar to viewing third party use as interfering with "normal exploitation" or creating "unreasonable prejudice" to the interests of the trademark owner. However, Article 17 explicitly shows deference to national legislatures to strike a fair balance between competing equal interests. ${ }^{165}$ A proper inquiry under international law would have treated the protection afforded to GIs under the TRIPS Agreement as a "floor" and scrutinized only the legitimacy of interests behind national legislation granting additional protection in light of the international minimum standard of trademark protection.

The theory of allocation of trademark rights based on a usebased property system explains the relationships between rights embedded in the TRIPS Agreement. Keeping in mind the necessary link between property rights allocation and enforcement it is inevitable that only governments can allocate trademark rights for their respective territories. ${ }^{166}$ It is within national jurisdiction to strike the final balance between the rights of trademark owners and third parties, since genuine conflicts can only be solved internationally by consensus, i.e. treaty amendment. In striking this balance, international law mandates that partial protection, and not absolute protection, be given to IPRs.

On the other hand, international law is the flip side of national law: obligations are allocated instead of rights. Contrary to the findings of the GI-Panel, it therefore naturally follows that the coexistence of all obligations is the norm. ${ }^{167}$ After all, a contract

165. Cf. TRIPS Agreement, supra note 1, art. 1.2.

166. Cf. Lemley, supra note 59, at 1072-73 (analogizing intellectual property to government-created subsidies).

167. The GI-Panel noted that the parties had not alleged a conflict between Article 16, section 1, and Article 24. EC Panel Report, supra note 6, II 7.624. Citing previous reports, the GI-panel recognized that there is a general presumption in international law against conflicts. Id. II $7.605,7.624$. These holdings, in which Member States raised a defense alleging conflict between obligations under different agreements, confirm the general principle of efficiency of treaty interpretation that presumes coexistence of treaty obligations and only supports a finding of formal conflict when an interpretation that avoids conflict is impossible. Panel Report, Turkey - Restrictions on Imports of Textile and Clothing Products, IIT 9.92-.95, WT/DS34/R (May 31, 1999); Appellate Body Report, 
is meaningless if a signatory can reap the benefits of international cooperation but opt out of its obligations. Hence an international instrument cannot be interpreted to allow one or some rights allocations at the national level to become supreme without destroying the system of international law. Instead all treaty interpretation should rest on the presumption of coexistence and conflict avoidance.

\section{CONCLUSION}

The TRIPS Agreement does not create an island of international intellectual property law that is isolated from both national and general international law. Instead its provisions should be interpreted in light of the agreement as a whole as well as its practical and contextual framework, according to established principles of customary international law. There are inherent limits to treaty interpretation imbedded in the rules of international jurisdiction and generally great deference should be shown to national legislatures in implementing the country's international obligations.

Viewing trademark rights as property rights can be both helpful and misleading on the international level. Acknowledging that property rights are inherently relational as well as subject to limitation in the public interest may prove useful when interpreting the provisions of the TRIPS Agreement, especially when the interests of holders of different IPRs are in potential conflict. Approaching the TRIPS Agreement as a complex system of rights allocation, instead of from the point of view of the individual rights holder, results in a more efficient use of all resources. A system premised on the coexistence of multiple users

\footnotetext{
Indonesia - Certain Measures Affecting the Automobile Industry, II 14.28, WT/DS54/R (July 2, 1998). The GI-Panel seems to conclude that since there is no formal conflict, there is no obligation under international law to consider the relationship between two provisions in the same treaty. The cited cases set forth the principle of coexistence of obligations as well as the rule of conflict-avoidance as general rules in treaty interpretation. These rules apply in all treaty interpretation regardless of whether a formal conflict is even alleged. See PAUwelyn, supra note 3, at 244. The GI-panel instead resorted to a purely literal interpretation of the text of the TRIPS Agreement according to the ordinary meaning of the words used. See EC Panel Report, supra note 6, II 7.620. A situation where WTO Panels has and thus legitimately can show less deference to national decisions is when the decision undermines the effectiveness of WTO rules, and could trigger damaging activities in other Member States. See JACKSON, supra note 3, at 161.
} 
of closely connected, yet distinguishable rights, naturally produces the most efficient result that the market can sustain.

WTO Panels should therefore tread carefully in areas of political contention applying a contextual approach to treaty interpretation based on an objective assessment of the obligations in the concluded agreement. Although the allocation of obligations in the TRIPS Agreement in this sense is static, interpretation should remain flexible for the purposes of continued development of national legislation in the field of intellectual property law. Promoting the gradual increase in standards of protection of IPRs on the global level is, after all, the objective and purpose of the TRIPS Agreement. 